\title{
SOME ROMAN BOARD GAMES ${ }^{1}$
}

\section{T.J. Leary, Hampton School, Middlesex, England}

Of the many themes treated in clever mock-didactic poems, table-games was one (Ovid Trist 2.485). Yet despite this, our knowledge is small and caution is always wise. What we know, we owe to Ovid, ${ }^{2}$ to Martial (14.13-18), to the so-called Laus Pisonis (P.L.M. 1.221f.) and to one or two sources of lesser account. We have, too, the evidence of archaeology, and this is important.

The games with which Ovid begins his several lists are the simplest - knucklebones and dice. Knucklebones first - these were rectangular, the ends rounded and unmarked. One played with four, the worst throw, termed the "dog" throw, resulting when all sides carne up the same. Conversely, "Venus", the highest score, saw each side different. ${ }^{3}$ One might throw merely for sport, or, although strictly illegal, ${ }^{4}$ might game for money.

Roman dice, much like ours, can be viewed in museums across England. Three were used (Isidore Orig 18.64), the highest score being a triple six (Aeschylus Ag 33). A tumbler called a fritillus (the word is onomatopoeic) was used to stop cheating. 5 Throwing dice might constitute a game in itself, or form part of a more complex game, like duodecim scripta described below.

Games simulating battles are still widespread today. One such in Roman times was the so-called "Game of robbers", Latrocinium or Lusus Latrunculorum, ${ }^{6}$ whose popularity is indicated by the number of boards surviving on which it was probably ${ }^{7}$ played. From the sources available, enough can be gleaned to reconstruct the game with some probability, although certainty escapes us.

Latrocinium boards were marked with lines and spaces, like a modern chess board, ${ }^{8}$ albeit not necessarily square. ${ }^{9}$ One played the game, in which no dice were used, with counters (glass at Ars 2.208) of a different colour to one's opponent's. As to how one began, or how many counters one had initially, we have no precise information. But for each player to start with two ranks across his side of the board seems sensible and is practicable.

1 This article, albeit simplified, bears some resemblance to a paper presented at the University of Cape Town in August 1988. Readers requiring more detail than is here provided are referred to Owen at Trist 2.471f., and the works of Bell, Austin and Paoli - see bibliography.

Ars 2.203f.; 3.353f.; Trist 2.471f.

Mart 14.14; Lucian Amores 16.

See Kay at Mart 11.6.2.

Mart 11.6.2. Dice boxes were also called turriculae - Mart 14.16.

Laus Pis 221f.; Ovid Trist 2.471 (and Owen ad loc); Ars 2.207-8; 3.357-60; Austin (1934:26f.); Bell (1979:84f.). Military terminology abounds when the game is described.

7 See Austin (1934:27) fig. 2.

The game has in fact often been compared with chess, but this is profitless and even confusing.

9 Austin's example ( $7 \mathrm{n}$. above) has seven squares by eight. 
The object was to capture enemy pieces by surrounding them with two of one's own - i.e. A B A, $\mathrm{B}$ being the piece taken. ${ }^{10}$ The player capturing the most enemy pieces won (Sen Dial 9.14.7). Presumably each player moved a piece in tum. To avoid capture, it was advisable always to kcep one's pieces in pairs - it was lone pieces that were vulnerable. "1 Surrounding an enemy piece would, however, involve separating a pair and therefore some consequent risk. This ensured excitement, and the need for perpetual vigilance.

An isolated piece was not necessarily doomed: backward moves were allowed (Laus Pis 198), and through skilful play a partner could be found in time. If not moving backwards or forwards, the player could surely move from side to side (Austin 1934:27). In addition, in the interests of speed and avoiding deadlock, it seems likely that a piece could move more than one square at a time (cf. possibly Laus Pis 198).

One of the games mentioned by Ovid in the context of boardgames, incongruously, ${ }^{12}$ requires not a board but a bag filled with balls, the object being to remove them one at a time without disturbing the others. Many variants of this game exist to the present, ranging from "spillikins" to stacking matchsticks on the top of beer bottles, with alcoholic penalties for those who disturb the pile.

Another board game to achieve popularity, judging both from literature and, again, from the boards which survive, ${ }^{13}$ was ludus duodecim scriptorum or duodecim scripta, the game of twelve points.

As to how it was played, there are no accounts. But reconstruction is possible (Austin 1934:33f.) given the board's evident kinship with modem-day backgammon, and that the rules of the related game Tabula, which became popular during the first century A.D., can be established with some precision. ${ }^{14}$

The boards are marked out thus: 15

$\begin{array}{lllllllllllll}\text { C } & \text { C } & \text { C } & \text { C } & \text { C } & \text { C } & * & \text { B } & \text { B } & \text { B } & \text { B } & \text { B } & \text { B } \\ \text { A } & \text { A } & \text { A } & \text { A } & \text { A } & \text { A } & * & \text { A } & \text { A } & \text { A } & \text { A } & \text { A } & \text { A } \\ \text { D } & \text { D } & \text { D } & \text { D } & \text { D } & \text { D } & * & \text { E } & \text { E } & \text { E } & \text { E } & \text { E } & \text { E }\end{array}$

10 Ovid Ars 3.358; Mart 14.17.2.

11 Pollux 9.98; Ovid Trist 2.478; Austin 1934:28f.

12 Some, for instance Brandt at Ars 3.361, suspect interpolation in consequence, especially given that the game is nowhere else described. Considering our ignorance concerning games, this seems extreme.

13 Owen at Trist 2.483 considers that the boards I, following Austin, associate with duodecim scripta were in fact employed in some other but similar game. This multiplication of games seems unnecessary and unwarranted.

14 Austin (1934:33); Bell (1979:34f.).

15 The numerate will notice not twelve marks but thirty-six. In this version of the board, however, the dots are not joined. The board can be marked in another style thus: 1111111111 . Instead of the letters A to E (cf. CIL xiv.5317), boards commonly had six words of six letters, each spelling advice to players (cf. Austin (1934:31)). 
It seems each player would enter his pieces - probably 15 (Austin 1934:33) - by alternate throws of the dice onto the markings $A$, and would then move them up through the alphabet to $E$, and then off the board. The first to remove all his pieces won. An opponent who occupied, with a single counter, a place to which your throw entitled you would have to give way, re-entering his piece in the normal fashion. With two counters, however, he could safely stand his ground.

The Roman equivalent of Noughts and Crosses is described by Ovid on two occasions, ${ }^{16}$ although no Roman name survives. It was played on a board of the following plan (the letters are editorial):

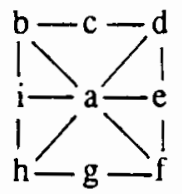

Each player, armed with three pieces (Ars 3.365), would enter his men on the board in tum, and then, by alternate moves, would try to get them three in a row - for example on points $b$ a $f$. The first person to succeed was the winner.

That other games existed, there can be no doubt (Ars 3.367). But they are lost to us - there was little point in a Roman's describing in detail what was common knowledge to all. That we have anything at all is, to a large extent, thanks to Ovid's poetic showmanship - elegiac couplets and table-game rule books are not generally associated, and the versification of such intractable material posed an inviting technical challenge. Indeed, his main intention in the Ars Amatoria was not to tell one how to play these games, but in what manner:

For although games present opportunities for amorous developments, women, it emerges, are not naturally good at losing, and must either leam some self-restraint or scare away their prey with a spectacle of bad behaviour (Ars 3.369f.). On the other hand, a woman allowed to win is a woman safely won - which was useful information for the predatory male (Ars 2.208).

\section{BIBLIOGRAPHY}

Austin, R.G. 1934. Roman board games I Greece and Rome 4, 24-34.

Austin, R.G. 1935. Roman board games II Greece and Rome 4, 76-82.

Bell, R.C. 1979. Board and table games of many civilisations, rev. ed. (2 vols in 1). New York.

Bell, R.C. 1980. Discovering old board games. Aylesbury.

Paoli, Ugo Enrico 1963. Rome: its people, life and customs, transl. R.D. Macnaughten. Longmans. 